\title{
An Investigation into Culturally-Loaded Words Teaching and Learning by Non-English Majors
}

\author{
Chen Guan, Yanan Zhao \\ Department of Foreign Languages, Baoding University, Baoding, China \\ Email: guanchen_1981@163.com
}

Received 9 February 2016; accepted 14 March 2016; published 17 March 2016

Copyright $(\subseteq 2016$ by authors and Scientific Research Publishing Inc.

This work is licensed under the Creative Commons Attribution International License (CC BY). http://creativecommons.org/licenses/by/4.0/

\begin{abstract}
Culturally-loaded words and expressions are the direct and indirect reflection of national culture in the structure of words and expressions. Improper use of culturally-loaded words may result in misunderstanding in cross-cultural communication. By means of paper test and questionnaire, this paper aims at investigating the current situation of culturally-loaded words teaching and learning among non-English majors in Baoding University. Some suggestions are proposed on how to improve culturally-loaded words teaching and learning based on the study result.
\end{abstract}

\section{Keywords}

Culturally-Loaded Words, Culture Differences, English Teaching \& Learning

\section{Introduction}

The College English Curriculum Requirements (2007) by the Ministry of Education of China emphasize the importance of students' well-rounded development, enabling students to communicate effectively, study independently and improve their general cultural awareness. To achieve this goal, college English teaching should focus on the cultivation of students' practical English proficiency. However, it is a pity to see that some Chinese college students are likely to offend others unconsciously and ruin communication, especially when it comes to cross-cultural communication. The reasons for the failure of communication may be various, but one of the major reasons is the absence of full understanding of culture differences and incorrect use of culturally-loaded words.

Everyone knows the importance of vocabulary in language learning as it is the foundation of understanding and communication. Linguist Wilkins (1976) once said, "Without grammar very little can be conveyed, without 
vocabulary nothing can be conveyed." Allen (1983) said that "lexical problems frequently interfere with communication; communication breaks down when people do not use the right words". With the development of modern linguistics, especially the rising of Pragmatics, students are encouraged to learn how to use words correctly and appropriately in different context, rather than reciting words without knowing how to use them. Culturally-loaded words, as a special group of words which contains cultural connotations besides their conceptual meaning, have attracted more and more attention home and abroad. This paper is to investigate Baoding University students' understanding and mastery of culturally-loaded words by test and questionnaire. Some suggestions are proposed based on the research result.

\section{Literature Review}

Wierzbicka (1997) says, "A word is the best evidence of the reality of culture, in the sense of a historically transmitted system of conceptions and attitudes.” Wu Guohua (1989) claims that "a human uses language as a communicative tool and the members of society utilize the meaning of words to communicate with each other according to the social cultural model of the nation”. As mentioned above, a word is a pure symbol, the relation between its sound and its meaning is utterly arbitrary. Some words share the same or similar meaning both in western and Chinese culture. Some words, although they refer to the same object, indicate different meanings in different cultures. Such words are culturally-loaded words. According to Hu (1999), "culturally-loaded words and expressions are loaded with specific national cultural information and indicate deep national culture. They are the direct or indirect reflection of national culture in the structure of words and expressions." Leech (1981) divides the meaning of words into seven parts: rational meaning, connotative meaning, social meaning, affective meaning, reflective meaning, collocating meaning and thematic meaning. According to Leech (1981), "conceptual meaning (sometimes called denotative or cognitive meaning) is widely assumed to be the central factor in linguistic communication...connotative meaning is the communicative value which an expression has by virtue of what it refers to, over and above its purely concept content”. Obviously, culturally-loaded words possess rich connotative meaning besides their conceptual meaning. They can be classified into different types according to different criteria. Based on different categories, culturally-loaded words can be divided into animal, figure, plant, body, machine, food, etc. In light of vocabulary equivalence, culturally-loaded words can be classified into the following types: complete equivalent, partially equivalent, completely contrary and lexical gap (Hu, 1988). The test of the animal words' connotation introduced in the following section is designed based on Hu's classification.

\section{Research Method}

\subsection{Subject}

One hundred non-English majors of Baoding University participated in the study as the research respondents. To ensure the study more generalized and representative, the students are from intact classes and their majors are Chinese and Applied Mathematics respectively. All the students are in their second year at college, aged between 19 and 23. Among them 44\% are male while 56\% are female. All the respondents have learned English over 7 years.

\subsection{Instrument}

The instrument includes two parts, Part I, a paper test about the connotation of animal words; Part II, a questionnaire about culturally-loaded words learning and teaching. In order to obtain a general picture of the status quo of the students' understanding and mastery of English culturally-loaded words, a paper test is given to the respondents. The items in the test are all animal words which are deeply culturally-rooted. The reasons for selection of animal words are as follows: Firstly, college students are more familiar with animal words compared with words in other fields. Animal words, especially the frequently-seen animal words, may be students' first mastery at the beginning of their English study. Therefore, animal words are least likely to be the obstacles in the process of students' understanding of the literal meaning so that the validity and reliability of the test can be ensured; secondly, in the long history of words development, animal words are deeply influenced by many factors, such as geographical region, religious belief, local customs, etc. The influence makes the animal words obtain connotative meaning besides its conceptual/denotative meaning. Animal words are good materials to check 
how well the college students understand culturally-loaded words. The test includes 10 items. Respondents are required to give the associative meaning of some English animal words according to their understanding of the culture of English-speaking countries. The test and questionnaire are made with the reference of the previous research made by Sui (2006) and Hu (2009) (Table 1 and Table 2).

\subsection{Data-Collection and Data-Analysis}

The data collected in the experiment are listed below:

The ten animal items are carefully selected according to their cultural connotative features. The first three, fox, pigeon and swan, have the similar cultural connotation both in English and in Chinese. So it is no surprising to see that most of the subjects can give the correct associative meaning of the three words. The test result shows that fox is predominantly associated with such adjectives as cunning, crafty, smart and fraudulent. Pigeon is the symbol of peace while swan represents elegance. The second group, made up of peacock, petrel and dragon, is characterized by the fact that the same animal words possess quite different connotations in English culture and Chinese culture. $49 \%$ subjects get the correct connotative meaning of peacock in English-speaking context, associating peacock with proud. In contrast, $51 \%$ students take peacock as the embodiment of luck and beauty under the influence of Chinese culture. As to petrel, $89 \%$ respondents regard it as a kind of brave seabird that fights the waves. However, westerners regard a stormy petrel as a person who is a herald of trouble, strife or violence. In case of dragon, only 38\% are deeply influenced by Chinese culture and link dragon to Chinese emperor or great power and majesty. It is glad to notice that more than half (62\%) of the subjects successfully separate the connotative meaning of dragon under western context from it in Chinese cultural environment, answering that dragon is the symbol of sin and evil. Lark and bee are the components of the third group which includes identical animal words with partially similar cultural connotations. Most students can tell the widely-accepted connotation of the two animals, that is, "to be cheerful" and "diligent" respectively. The reason why the percentage of correction doesn't reach a high level is that only a few students know the extra connotative meaning of the two animals besides their basic connotation. Lark also means "a bit of adventurous fun" and bee "person is crazy for something". The last two words oyster and beaver are classified into animal words with the rich connotations in English, but vacant in Chinese. It can be a good explanation why the percentage of correction of this group is the lowest compared with other animal words. Oyster is used to describe a silent person in English. While in Chinese, it only refers to a kind of shellfish with no special meaning. Just like oyster, beaver has no special connotation in Chinese, while it is used to refer to a person who works hard especially for currying favor with the superior in English. Therefore, animal words with unique cultural connotations in original language are not easily understood by the target language readers.

The following is the statistics of the Questionnaire about culturally-loaded words learning and teaching and analysis of the statistics.

The first two questions aims at investigating students' interest in western and Chinese culture. The result shows that most students are interested in cultures, both western and Chinese. A striking contrast is reflected with the data of Q3. Despite great interest in western and Chinese culture, only 52 subjects sometimes compare western culture with traditional Chinese culture, and 31 seldom make the comparison. Q4 corresponds to Q3 to some extent, indicating that the number of students who usually compare the different meaning of the same subject in terms of western and Chinese culture is rather low. Q5 is designed to investigate students' difficulty due to unfamiliar western cultural factors in reading English books. The majority of subjects say they usually or sometimes are confused (94 subjects all together). From the data of Q6, it can be told that nearly half subjects (49 students) seldom pay attention to cultural connotations while meeting new words. The last three questions are proposed to make clear the status quo of teachers' teaching of culturally-loaded words. Generally speaking, English teachers attach great importance to culture teaching by introducing cultural background information before study of text (Reflected through the data of Q7). As to the specific culturally-loaded words teaching (Q8), in case of "usually", the figure falls from 86 to 63, indicating that teachers pay less attention to the illustration

Table 1. Performance on single item of Part I of the test.

\begin{tabular}{ccccccccccc}
\hline Animal words & Fox & Pigeon & Swan & Peacock & Petrel & Dragon & Lark & Bee & Oyster & Beaver \\
\hline Percentage of correctness & $98 \%$ & $95 \%$ & $90 \%$ & $49 \%$ & $11 \%$ & $62 \%$ & $45 \%$ & $56 \%$ & $9 \%$ & $5 \%$ \\
\hline
\end{tabular}


Table 2. Statistics of the questionnaire about culturally-loaded words learning and teaching.

\begin{tabular}{|c|c|c|c|}
\hline \multirow[b]{2}{*}{ Questions about culturally-loaded words } & A & B & $\mathrm{C}$ \\
\hline & $\begin{array}{c}\text { Interested } \\
\text { usually }\end{array}$ & $\begin{array}{l}\text { Not very interested } \\
\text { sometimes }\end{array}$ & $\begin{array}{l}\text { No interest at all } \\
\text { seldom }\end{array}$ \\
\hline 1. Are you interested in western culture? & 72 & 23 & 5 \\
\hline 2. Are you interested in traditional Chinese culture? & 81 & 17 & 2 \\
\hline 3. Do you make comparison between western culture and traditional Chinese culture? & 12 & 57 & 31 \\
\hline $\begin{array}{l}\text { 4. Do you compare the different meaning of the same subject in terms of western and } \\
\text { Chinese culture, such as dragon, or dog? }\end{array}$ & 15 & 55 & 30 \\
\hline 5. Are you confused with some western cultural factors while reading English books? & 49 & 45 & 6 \\
\hline 6. Do you pay attention to cultural connotations while meeting new words? & 25 & 26 & 49 \\
\hline $\begin{array}{l}\text { 7. Does your English teacher introduce related culture background to you before the } \\
\text { study of text? }\end{array}$ & 86 & 10 & 4 \\
\hline $\begin{array}{l}\text { 8. Does your English teacher explain the words' cultural meaning to you when teaching } \\
\text { vocabulary? }\end{array}$ & 63 & 24 & 13 \\
\hline $\begin{array}{l}\text { 9. Does your English teacher explain the words' cultural meaning by comparing } \\
\text { Chinese culture with western culture? }\end{array}$ & 27 & 36 & 37 \\
\hline
\end{tabular}

(The choices for the first three questions are marked as A interested, B not very interested and C not interested at all; the choices for the rest questions are listed as A usually, B sometimes and C seldom.)

and explanation of culturally-loaded words despite that they usually introduce general western cultural background. Q9 aims at investigating how often English teachers employ contractive method, which is a very important method to teach connotative meaning of words, when introduce culturally-loaded words to students. The figure is not very satisfactory. More than one third of students (37) say that their English teachers seldom use this method.

Although the research reveals some trends in culturally-loaded words teaching and studying, it does have some limitations. Firstly, only one hundred students participated in the research, and they were from only two majors. The relatively small sample size and limited majors made the research result not representative enough. Secondly, the questionnaire was designed with inspiration of previous related research, and the reliability of the questionnaire was not clarified. These limitations will be attached to great importance and the reliability will be enhanced in the later study.

\section{Suggestions for Teaching Culturally-Loaded Words in College English}

From the analysis of the result of the test and questionnaire shown above, it can be concluded that culturallyloaded words teaching is quite necessary and important and there is still a lot of work to do. Next the writer of this paper will make some suggestions on how to enhance the culturally-loaded words teaching from the perspective of teachers and students respectively.

\subsection{Suggestions for College English Teacher}

The result of research indicates that college English teachers have done a great job in culturally-loaded words teaching. For example, to facilitate students' understanding of text, teachers usually introduce the related culture background first before the formal text study. But what deserves our attention is that some teachers don't know how to teach culturally-loaded words better. Therefore, some suggestions are proposed here. Hopefully, it may be helpful in the future teaching.

First, college English teachers should enhance their own awareness of culture differences. Without teachers' profound knowledge of western and Chinese culture, there is no way for students to have keen culture awareness. Teachers should receive professional and academic training for the teaching of culture. They should also keep a sharp eye on the sparks generated by the diversity of different cultures.

Second, college English teachers should equip themselves with the latest linguistic and pedagogical theories related to vocabulary teaching. It has been proved that contrastive method is one of the widely-used and most 
effective techniques in cultural teaching. This method refers to teaching students cultural connotations through comparing the native culture and the target culture. As the test result shows, students are more likely to have the correct answer when the test items have the same or similar connotation in English and Chinese. But when it comes to the items with different connotations, the correct rate falls sharply. Contrastive method can be applied in this case. It can clearly make differences between English and Chinese cultures and help students to rapidly develop intercultural communicative awareness.

Third, college English teachers should strengthen students' autonomous leaning ability by providing them with more opportunities to explore, observe and draw conclusion by themselves. The result of the questionnaire indicates that although students have already realized teachers' effort on culture and culturally-loaded words teaching, they themselves seldom make comparison of the same or different connotative meaning of culturally-loaded words. Teachers should play the role of guide, guiding students to reading books or watching movies with rich cultural context according to their own experiences and cultural knowledge. They should play the role of tutor, helping students to hold seminar with the topic related to culture, etc. In this way, students may receive guidance or instructions on efficient learning of culturally-loaded words.

\subsection{Suggestions for College Students}

In order to improve their cultural communicative competence, students also need to enhance their awareness and sensitivity of culture differences, especially pay more attention to culturally-loaded words. Meanwhile, they should fulfill autonomous learning effectively (Guan and Li, 2014). With the fast development of science and technology, students have more access to the diversity of different cultures. They are encouraged to grasp the good opportunity to make comparison between western and Chinese culture. Take the word "dragon" as an example, which is also selected as test item in the previous test paper. As Chinese people, we are quite familiar with the connotative meaning of dragon in Chinese culture. We have already associated the imaginary animal with such words as imperial power or majesty. The word dragon takes appreciative meaning in Chinese culture. However, in western culture, the interpretation of the word dragon is quite different from what we have in China. Dragon, as a symbol of sin, has been depicted as a ferocious monster with the ability to breathe fire in many literary works and films, such as epic poem Beowulf, J. K Rowling's Harry potter and the goblet of fire. With the help of Internet, students can also track western people's negative attitude toward dragon. Book of Revelation reads 'War breaks out in heaven between Michael and the Dragon, identified as that old Serpent, the Devil, or Satan (12:9)'. The explanation of the word dragon is only an example. Students can learn more about the culturally-loaded words via various channels, such as surfing the Internet, chatting with foreign friends through MSN, watching films and attending online micro-class, etc. In the process of autonomous learning, they can enhance their culture awareness and improve their self-study ability and cultural communicative ability.

\section{Conclusion}

By means of paper test and questionnaire, this paper finished its study purpose of investigating the current situation of culturally-loaded words teaching and learning among non-English majors in Baoding University. Through the data analysis, it's glad to see that both teachers and students are well aware of the importance of cross-cultural communication and the significant function culturally-loaded words play in it. However, some phenomena reflected through the research result deserve great attention. As for students, they are eager to know the diversity of different cultures but lack of autonomous learning motivation and methods. They seldom make comparison between denotative and connotative meaning of words in different cultures, which directly leads to their misunderstanding of the different connotations of the same animal image in English and Chinese culture respectively. As for teachers, in spite of the fact that they have great enthusiasm in cross-culture teaching by taking methods like introducing culture background before text study and explaining words' cultural connotative meanings, etc. unfortunately, they don't explain words' cultural meaning by comparing Chinese culture with western culture frequently. It is better to apply some scientific pedagogical methods to culturally-loaded words teaching, such as contrastive teaching method to compare the different connotations of culturally-loaded words.

With the rapid development of global communication, college English teaching must attach great priority to enhance students' cross-cultural competence. Teachers and students should work together to figure out the effective measures to improve students' cross-cultural competence, including their mastery of culturally-loaded words. Only in this way can establish and promote successful cross-cultural communication and realize the 
teaching goals.

\section{References}

Hu, Q. M. (2009). A Study on the Cultural Connotation Differences between Some English and Chinese Words and Culturally-Loaded Words Teaching of College English. Master Dissertation, Beijing: Capital Normal University.

Hu, W. Z. (1988). Intercultural Communication-What It Means to Chinese Learners of English. Shanghai: Shanghai Translation Publishing House.

Hu, W. Z. (1999). Aspects of Intercultural Communication. Beijing: Foreign Language Teaching and Research Press.

Leech. G. (1981). Semantics. Harmondsworth: Penguin Books Ltd.

Ministry of Education of China (2007). College English Curriculum Requirements. Shanghai: Shanghai Foreign Language Education Press.

Sui, D. (2006). A Study of Teaching Culture-loaded Words in English Language Teaching in Chinese Secondary Schools. Master Dissertation, Jinan: Shandong Normal University.

Wierzbicka, A. (1997). Understanding Cultures through Their Key Words. London: Oxford University Press. 